\title{
Hypoxic conditions and iron restriction affect the cell-wall proteome of Candida albicans grown under vagina-simulative conditions
}

\author{
Grazyna J. Sosinska, Piet W. J. de Groot, M. Joost Teixeira de Mattos, \\ Henk L. Dekker, Chris G. de Koster, Klaas J. Hellingwerf and Frans M. Klis
}

\begin{abstract}
Correspondence
Grazyna Sosinska

sosinska@science.uva.n
\end{abstract}

Received 21 August 2007

Revised 12 October 2007

Accepted 15 October 2007
Swammerdam Institute for Life Sciences, University of Amsterdam, Nieuwe Achtergracht 166, 1018 WV, Amsterdam, The Netherlands

\section{INTRODUCTION}

Candida albicans is a pleiomorphic pathogenic fungus that is responsible for many mucosal infections in humans, and may cause systemic, often fatal infections in immunocompromised patients (Calderone, 2002). It is also well equipped to form biofilms on abiotic surfaces such as dentures and medical devices (Blankenship \& Mitchell, 2006; Ramage et al., 2006). Covalently linked cell-wall proteins (CWPs) play an important role in initiating and maintaining mucosal infections and biofilms (De Groot et al., 2007; Li et al., 2007; Naglik et al., 2006; Nobile et al., 2006; Richard \& Plaine, 2007; Ruiz-Herrera et al., 2006; Sundstrom, 1999; Zhao et al., 2006; Zupancic \& Cormack, 2007). This is consistent with their cellular location because covalently linked CWPs form an external protein layer surrounding the internal skeletal polysaccharide layer of the wall, and thus come directly into contact with biotic and abiotic surfaces. As in Saccharomyces cerevisiae, the cell-wall proteome of C. albicans consists of 15 or more covalently linked CWPs and includes structural proteins,

Abbreviations: CWP, cell-wall protein; GPI, glycosylphosphatidylinositol; VSM, vagina-simulative medium; YNB, yeast nitrogen base. adhesion proteins, carbohydrate-active proteins, proteases, superoxide dismutases and iron-acquisition proteins (Albrecht et al., 2006; De Groot et al., 2004; Garcera et al., 2005; Mao et al., 2003; Weissman \& Kornitzer, 2004). In agreement with the outcome of similar studies carried out with S. cerevisiae, genomic transcript profiling studies of $C$. albicans indicate that the composition of the cell-wall proteome may vary considerably with the growth conditions of the organism. For example, both yeast and hyphal walls seem to possess specific CWPs (Sohn et al., 2003; Staab et al., 1999). The expression of several CWPencoding genes changes when Candida cells become associated with different human epithelia or with abiotic surfaces (Garcia-Sanchez et al., 2004; Sohn et al., 2006), when transferred to blood (Fradin et al., 2005), or when confronted with environmental stress conditions such as low or high pH (Bensen et al., 2004), the presence of azoles in the medium (De Backer et al., 2001; Liu et al., 2005), which interferes with sterol synthesis, or the presence of caspofungin, which inhibits the synthesis of the skeletal polysaccharide $\beta$-1,3-glucan and thereby causes cell-wall stress (Liu et al., 2005). Iron deprivation and hypoxic conditions are also known to affect the expression of CWPencoding genes (Lan et al., 2004; Setiadi et al., 2006). 
Collectively, these observations strongly suggest that the composition of the cell-wall proteome may vary considerably, both qualitatively and quantitatively, depending on environmental cues.

Many Candida infections involve colonization of the vaginal mucosal layer (Fidel \& Sobel, 2002; Sobel, 2007). About three-quarters of all women suffer from vaginitis at least once during their life time. Vaginal environmental conditions are characterized by a relatively low $\mathrm{pH}$, a high partial pressure of $\mathrm{CO}_{2}$ (approx. $6 \%, \mathrm{v} / \mathrm{v}$ ) and low to vanishing partial pressures of $\mathrm{O}_{2}(\leqslant 10 \%, \mathrm{v} / \mathrm{v})$.

In this study, we have analysed the cell-wall proteome of $C$. albicans cells grown in vagina-simulative medium (VSM) at $6 \% \mathrm{CO}_{2}(\mathrm{v} / \mathrm{v})$ and at $\mathrm{O}_{2}$ levels ranging from 7 to $0.01 \%$ $(\mathrm{v} / \mathrm{v})$. We also studied the effect of iron availability by growing the cells at $7 \% \mathrm{O}_{2}$ with an iron chelator. Our results show that under these conditions a new set of CWPs is incorporated into the walls compared to cells grown in rich medium at pH 5-5.6 (De Groot et al., 2004). At restrictive $\mathrm{O}_{2}$ concentrations the levels of at least four CWPs increase, i.e. the structural protein Pirl, the adhesion protein Hwpl and, in particular, Pga10 and Rbt5, two iron-acquisition proteins. These observations are consistent with the notion that hypoxic conditions may lead to a cellular response that involves an increased scavenging capacity for iron.

\section{METHODS}

Strains and growth conditions. The $C$. albicans strains used in this study are listed in Table 1. VSM was modified from Moosa et al. (2004) and Owen \& Katz (1999) and consisted of $58 \mathrm{mM} \mathrm{NaCl}$, $18 \mathrm{mM} \mathrm{KOH}, 2 \mathrm{mM} \mathrm{Ca}(\mathrm{OH})_{2}, 1.75 \mathrm{mM}$ glycerol, $6.7 \mathrm{mM}$ urea, $33 \mathrm{mM}$ glucose, and $6.7 \mathrm{~g}$ yeast nitrogen base (YNB) $1^{-1}$ (Difco). In addition, lactic acid $\left(22 \mathrm{mM} ; \mathrm{p} K_{\mathrm{a}}=3.85\right)$ and acetic acid $(17 \mathrm{mM}$; $\mathrm{p} K_{\mathrm{a}}=4.76$ ), which are natural compounds in the vaginal fluid, were added to maintain the $\mathrm{pH}$ at 4.2. Strains were pre-cultured to saturation in YPD medium [1\% (w/v) Bacto-yeast extract; $2 \%(\mathrm{w} / \mathrm{v})$ Bacto-peptone; $2 \%$ glucose $(\mathrm{w} / \mathrm{v})]$ at $30{ }^{\circ} \mathrm{C}$ and 200 r.p.m. The cells were then inoculated in VSM in batch fermenters (working volume $0.5 \mathrm{l}$ ) at $37^{\circ} \mathrm{C}$ with an aeration rate of $0.51 \mathrm{~min}^{-1}$ and stirred at 200 r.p.m. The cells were cultured overnight under ambient air to an $\mathrm{OD}_{600}$ of $\sim 0.1$; aeration was subsequently switched to gas mixtures, consisting of $\mathrm{N}_{2}, 0.01-7 \%(\mathrm{v} / \mathrm{v}) \mathrm{O}_{2}$ and $6 \%(\mathrm{v} / \mathrm{v}) \mathrm{CO}_{2}$, which leads to dissolved $\mathrm{O}_{2}$ concentrations that correspond to values measured in the human vagina (Wagner \& Ottesen, 1982). The cells were harvested at an $\mathrm{OD}_{600}$ of $\sim 1$. To induce iron restriction, $1 \mathrm{mM}$ ferrozine [5,6-diphenyl-3-(2-pyridyl)-1,2,4-triazine- $4^{\prime}, 4^{\prime \prime}$-disulfonic acid; Sigma-Aldrich] was added to overnight cultures at $\mathrm{OD}_{600}$ $\sim 0.1$. Culturing was continued until an $\mathrm{OD}_{600} \sim 1$ was reached and the cells were collected for cell-wall analysis. The $\mathrm{OD}_{600}$ of cultures was measured using a Shimadzu model UV mini 1240 spectrophotometer $\left(\mathrm{OD}_{600}=1\right.$ corresponds to $1.5 \times 10^{7}$ cells $\left.\mathrm{ml}^{-1}\right)$. To determine the percentage of budded cells (the budding index), 200 cells were taken from two independent cultures for each condition and counted. Relative growth rates were determined by following the $\mathrm{OD}_{600}$ of three separate cultures in the range $\mathrm{OD}_{600} \sim 0.1$ to $\sim 1$. A reference cell culture grown in rich medium ( $\mathrm{pH}$ 5.5) (Table 2) was obtained as follows. The medium consisted of $20 \mathrm{~g}$ glucose $\mathrm{l}^{-1}, 10 \mathrm{~g}$ Casamino

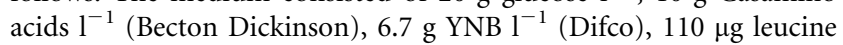
$\mathrm{ml}^{-1}, 55 \mu \mathrm{g}$ tyrosine $\mathrm{ml}^{-1}, 55 \mu \mathrm{g}$ tryptophan $\mathrm{ml}^{-1}$ and $55 \mu \mathrm{g}$ adenine sulfate $\mathrm{ml}^{-1}, \mathrm{pH} 5.5$, as described by De Groot et al. (2004). The cells were cultured overnight in a batch fermenter aerated with atmospheric air with stirring at 200 r.p.m. at $30{ }^{\circ} \mathrm{C}$ and were harvested at mid-exponential phase.

Cell-wall isolation. Cell walls were isolated as described previously (De Groot et al., 2004). Cultures were harvested in the exponential phase of growth, washed with cold demineralized water and with $10 \mathrm{mM}$ Tris/ $\mathrm{HCl}$ buffer, $\mathrm{pH} 7.5$, and disintegrated in a Bio-Savant Fast Prep 120 machine (Qbiogene), using 0.25-0.50 mm diameter glass beads (Emergo BV). A protease inhibitor mixture (SigmaAldrich) was added to protect CWPs from degradation by intracellular proteases. To remove non-covalently linked proteins associated with the wall preparation, crude cell walls were washed with $1 \mathrm{M} \mathrm{NaCl}$ and boiled twice for $5 \mathrm{~min}$ in $2 \%(\mathrm{w} / \mathrm{v}$ ) SDS, $150 \mathrm{mM}$ $\mathrm{NaCl}, 100 \mathrm{mM}$ Na-EDTA, $100 \mathrm{mM} \beta$-mercaptoethanol, $50 \mathrm{mM}$ Tris/ $\mathrm{HCl}$, at $\mathrm{pH}$ 7.8. SDS-extracted walls were washed three times with demineralized water and freeze-dried.

Sample preparation for MS analysis. For MS analysis, CWPs were modified by reduction and $S$-alkylation as follows. Cell walls were treated with the reducing reagent $10 \mathrm{mM}$ dithiothreitol in $100 \mathrm{mM}$ $\mathrm{NH}_{4} \mathrm{HCO}_{3}$ for $1 \mathrm{~h}$ at $55{ }^{\circ} \mathrm{C}$. The samples were then cooled and the walls were alkylated by incubating them for $45 \mathrm{~min}$ at room temperature in the dark in $65 \mathrm{mM}$ iodoacetamide in $100 \mathrm{mM}$ $\mathrm{NH}_{4} \mathrm{HCO}_{3}$. The reaction was quenched by incubating the walls in $55 \mathrm{mM}$ dithiothreitol in $100 \mathrm{mM} \mathrm{NH} \mathrm{NCO}_{3}$ for $5 \mathrm{~min}$. Prior to digestion with trypsin, the walls were washed three times with $50 \mathrm{mM}$ $\mathrm{NH}_{4} \mathrm{HCO}_{3}$. Trypsin digestion of $S$-alkylated CWPs was carried out as described by Yin et al. (2005). Cell walls were incubated overnight at $37^{\circ} \mathrm{C}$ in the presence of sequencing-grade trypsin (Roche Applied Science) using a CWP/enzyme ratio of $50: 1$.

MS identification of covalently linked CWPs. Instrument and analysis settings were as described by Yin et al. (2005). Tryptic peptides $(5-10 \mu \mathrm{g})$ were desalted and concentrated on a C18-ZipTip pre-column (Millipore) and fractionated using a nano-LC system (PepMap C18; LC Packings, Dionex). Eluted peptides were directly ionized by electrospray in a Micromass quadrupole time-of-flight mass spectrometer (Waters). The ions from the survey spectrum were

Table 1. C. albicans strains used in this study

\begin{tabular}{|c|c|c|}
\hline Strain & Description & References \\
\hline SC5314 & Clinical isolate & Fonzi \& Irwin (1993) \\
\hline CAF 2-1 & ura3s: : imm434/URA3 & Fonzi \& Irwin (1993) \\
\hline KC85 & 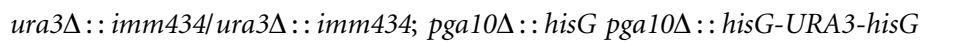 & Weissman \& Kornitzer (2004) \\
\hline KC100 & 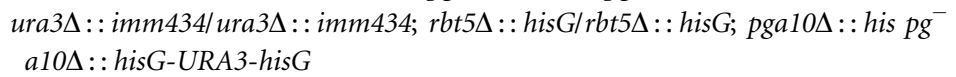 & Weissman \& Kornitzer (2004) \\
\hline
\end{tabular}


Table 2. Proteins identified by LC/MS/MS or immunoblot analysis in cell walls isolated from cultures grown in VSM in the presence of $7-0.01 \% \mathrm{O}_{2} / 6 \% \mathrm{CO}_{2}$

For comparison, the CWPs identified in cells from a reference culture grown in rich medium and aerated with atmospheric air are also presented. +, Detected by MS/MS; -, not detected by MS/MS; + +, detected by immunoblot; - -, not detected by immunoblot.

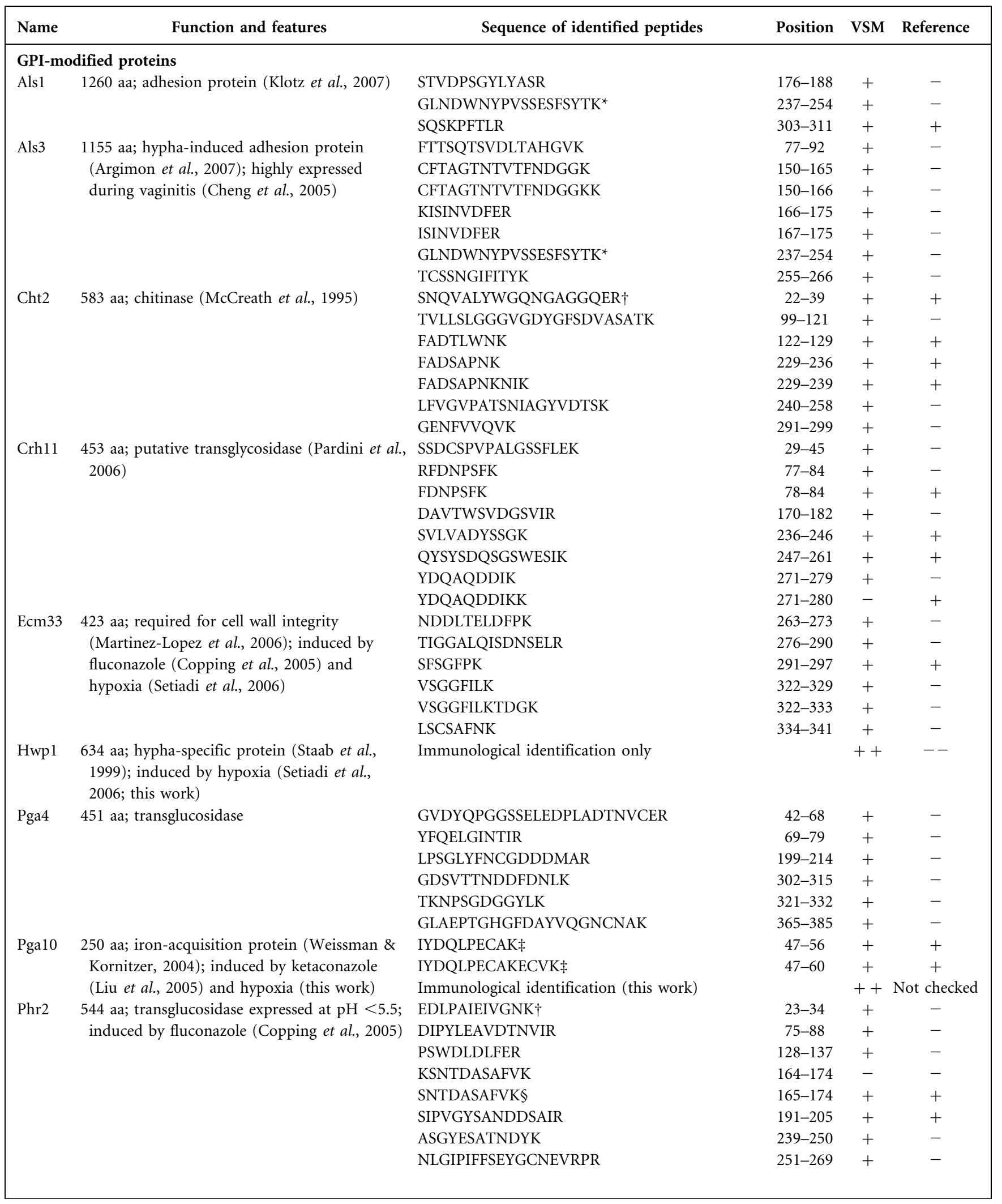


Table 2. cont.

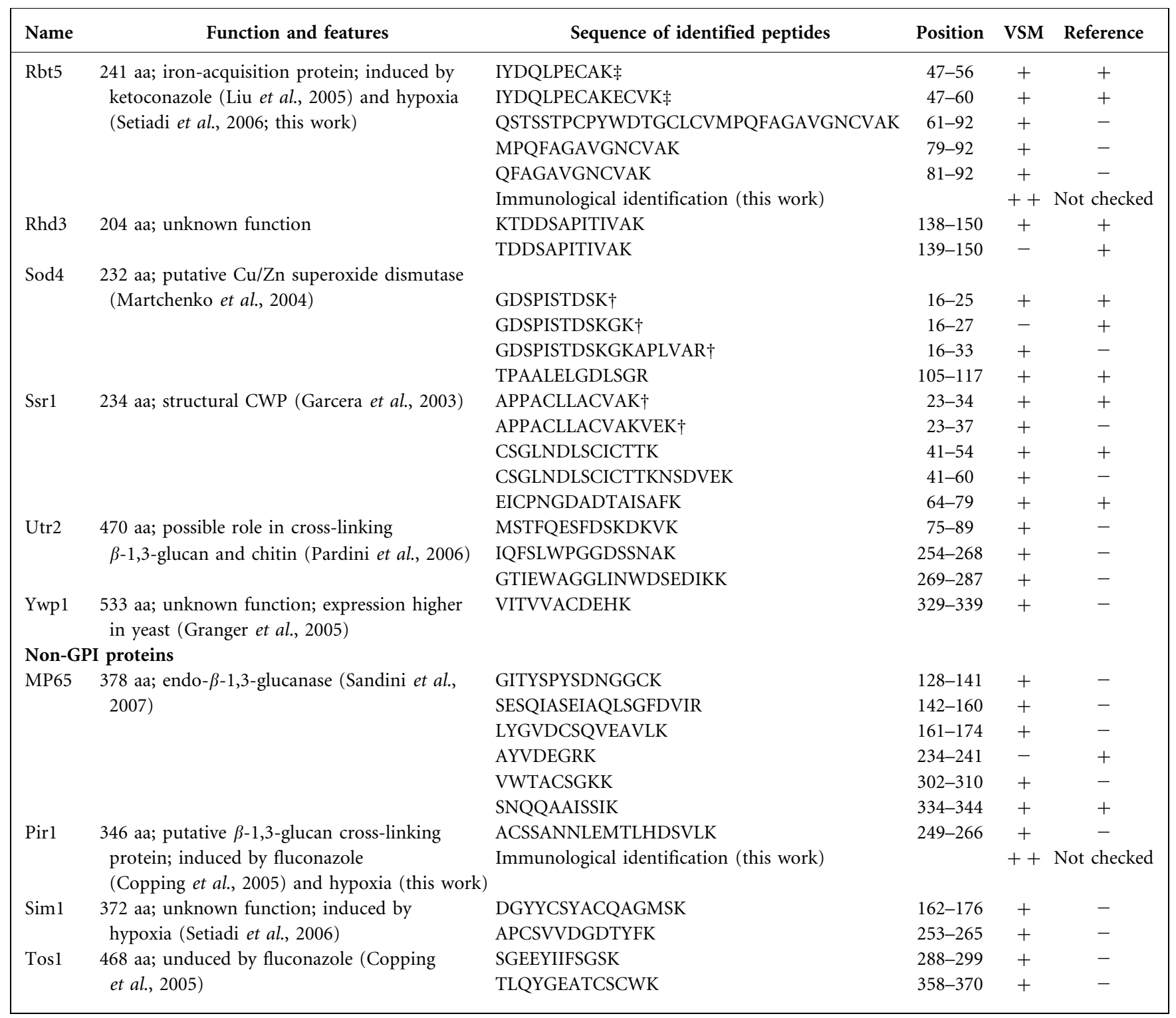

${ }^{\star}$ Common peptide of Als1 and Als3.

$\dagger$ Predicted N-terminal peptide of the mature protein.

¥Common peptide of Pga10 and Rbt5.

§Common peptide of Phr1 and Phr2.

automatically selected for fragmentation in a collision chamber using Masslynx software. Tandem MS spectra of ionized peptide fragments were analysed with Biolynx and Masslynx Pepseq software. Proteins were identified by comparison of the identified amino acid peptide sequences with in silico digests of the proteins translated from Assembly 19 of the C. albicans SC5314 genome sequence (www. candidagenome.org/) using Mascot software. Several precautions were taken to optimize the reproducibility of the results over time and to monitor drift of the equipment. (1) The nano-LC column was cleaned daily by thoroughly washing it with $100 \%$ solvent B (acetonitrile $+0.1 \%$ formic acid). (2) To prevent carry over from previous samples, at least one empty injection was run between each sample. (3) The amount of sample loaded in the LC step of each run was measured using an $A_{214}$ chromatogram. (4) To control the efficiency of ionization and to verify that the run-to-run variation of the ion intensity was $<20 \%$, the total ion count (TIC) profile of each LC/MS/MS run was determined. (5) To verify the accuracy of MS selection, the instrument was calibrated daily with 1 pmol cytochrome $c$ (Dionex). (6) Each sample (containing $\sim 1$ pmol protein) was run at least three times, and in two of them the exclusion list was used to ensure complete coverage. (7) The general performance of the LC/MS/MS system was checked monthly with a cytochrome $c$ digest to verify that a similar number of peptides of similar Mascot score were identified.

Isolation of CWPs for immunoblot analysis. Glycosylphosphatidylinositol (GPI)-modified CWPs were released by treating cell-wall material with recombinant Trichoderma harzianum endo- $\beta-1,6-$ glucanase (Bom et al., 1998) as described by Kapteyn et al. (2001). 
Freeze-dried cell walls $(4 \mathrm{mg})$ were incubated overnight with $2.5 \mu \mathrm{l}$ $\left.[0.16 \mathrm{U} \text { (mg cell walls })^{-1}\right]$ enzyme and $2 \mu \mathrm{l}$ of a protease inhibitor mixture (Sigma-Aldrich) in $200 \mu 150 \mathrm{mM}$ sodium phosphate buffer, $\mathrm{pH} 5.5$, at $37^{\circ} \mathrm{C}$ overnight. To release mild alkali-extractable CWPs, cell walls were incubated with $30 \mathrm{mM} \mathrm{NaOH}$ at $4{ }^{\circ} \mathrm{C}$ for $17 \mathrm{~h}$ with gentle shaking; the reaction was stopped by neutralization with $30 \mathrm{mM}$ acetic acid (Mrša et al., 1997). In each lane, the equivalent of $0.15 \mathrm{mg}$ dried walls (corresponding to $\sim 1 \mathrm{mg}$ dried biomass) was applied.

Immunoblot analysis of CWPs. CWPs were separated by electrophoresis using linear 3-8\% polyacrylamide gradient gels in Tris/acetate (Invitrogen). The separated proteins were transferred onto an Immobilon polyvinylidene difluoride (PVDF) membrane (Millipore). To reduce non-specific staining by the antisera, the membrane-blotted proteins were first incubated with $50 \mathrm{mM}$ periodic acid in $100 \mathrm{mM}$ sodium acetate ( $\mathrm{pH} 4.5$ ) prior to the blocking step. Immunoblot analysis was performed with polyclonal Hwp1 (Staab et al., 1996) or Pga10 antiserum (Weissman \& Kornitzer, 2004), diluted $1: 10000$ in $5 \%(\mathrm{w} / \mathrm{v})$ milk powder in PBS buffer, $\mathrm{pH} 7.4$, for 2 h. $S$. cerevisiae Pir2 antiserum (Russo et al., 1992) was diluted 1:50000 and incubated with the blots overnight to enhance interaction with the probed proteins. After washing with PBS, the membranes were incubated with goat anti-rabbit antiserum, conjugated with peroxidase (GARPO) at a dilution of $1: 10000$ in $5 \%(\mathrm{w} / \mathrm{v})$ milk powder in PBS buffer, $\mathrm{pH}$ 7.4. Proteins were visualized using Enhanced Chemiluminescence (ECL) (Amersham Biosciences).

Quantazyme sensitivity. Quantazyme sensitivity of intact cells was measured as described by Kapteyn et al. (2001). Exponentially growing cells were centrifuged and washed twice with $50 \mathrm{mM}$ Tris/ $\mathrm{HCl}, \mathrm{pH}$ 7.5. The $\mathrm{OD}_{600}$ of the cell suspensions was adjusted to 1 and the cells were pre-incubated for $1 \mathrm{~h}$ with $40 \mathrm{mM} \beta$-mercaptoethanol in $50 \mathrm{mM}$ Tris/ $\mathrm{HCl}$ buffer, $\mathrm{pH}$ 7.5. Quantazyme (from Oerskovia xanthineolytica; Quantum Biotechnologies) was added at $20 \mathrm{U}(\mathrm{ml}$ cell suspension $)^{-1}$. Incubation was carried out at $30{ }^{\circ} \mathrm{C}$, and the decrease in $\mathrm{OD}_{600}$ was measured at 5 min intervals.

Determination of the polypeptide and chitin content of isolated cell walls. Cell walls ( $4 \mathrm{mg}$ ) were suspended in $100 \mu \mathrm{l} 1 \mathrm{M} \mathrm{NaOH}$. The suspension was incubated at $100{ }^{\circ} \mathrm{C}$ for $10 \mathrm{~min}$, cooled and neutralized with $100 \mu 11 \mathrm{M} \mathrm{HCl}$. Insoluble material was pelleted by centrifugation and the supernatant was used for protein determination using the bicinchoninic acid protein assay (Pierce). A calibration curve was prepared by using BSA treated in the same way as the cell wall samples.

Chitin content was measured using the method described by Kapteyn et al. (2001). $\mathrm{NaOH}$-extracted (4 mg; see protein determination above) cell walls were hydrolysed for $17 \mathrm{~h}$ in $1 \mathrm{ml} 6 \mathrm{M} \mathrm{HCl}$ at $100{ }^{\circ} \mathrm{C}$. Samples were evaporated under a stream of air and resuspended in $1 \mathrm{ml}$ de-mineralized water. To $0.1 \mathrm{ml}$ sample, $0.1 \mathrm{ml} 1.5 \mathrm{M} \mathrm{Na}_{2} \mathrm{CO}_{3}$ in $4 \%$ acetylacetone was added and the mixture was boiled for $20 \mathrm{~min}$. After cooling, $0.7 \mathrm{ml} 96 \%$ ethanol and $0.1 \mathrm{ml} 1.6 \mathrm{~g} \mathrm{p}$ dimethylaminobenzaldehyde in $30 \mathrm{ml}$ concentrated $\mathrm{HCl}$ and $30 \mathrm{ml}$ $96 \%(\mathrm{v} / \mathrm{v})$ ethanol were added before incubation for $1 \mathrm{~h}$ at room temperature. A calibration curve was prepared by measuring $A_{520}$ in a concentration range of $0-40 \mu \mathrm{g}$ glucosamine $\mathrm{ml}^{-1}$.

\section{RESULTS}

\section{The effect of changes in the gas-phase composition on the relative growth rate and cell- wall composition of C. albicans grown in VSM}

For the studies reported in this communication we used a growth medium consisting of YNB with modified concentrations of calcium, chloride, potassium and sodium ions, conforming to the concentrations in the vaginal fluid of healthy pre-menopausal women during the nonmenstrual phase (Owen \& Katz, 1999) (Methods). The medium further contained urea and glycerol and was buffered at $\mathrm{pH} 4.2$ by making use of the physiological buffers found in the vaginal fluid, i.e. $22 \mathrm{mM}$ lactic acid $\left(\mathrm{p} K_{\mathrm{a}} 3.85\right)$ and $17 \mathrm{mM}$ acetic acid $\left(\mathrm{p} K_{\mathrm{a}} 4.76\right)$ (Owen \& Katz, 1999). Glucose, which is present in the vaginal fluid at a concentration of $\sim 33 \mathrm{mM}$, served as the main carbon source. The cells were grown at $37^{\circ} \mathrm{C}$. The microenvironment of the human vagina is characterized by lower $\mathrm{O}_{2}$ and higher $\mathrm{CO}_{2}$ levels compared to atmospheric values; (Wagner \& Ottesen, 1982). The $\mathrm{O}_{2}$ concentrations measured in the vaginal fluid vary from almost 0 to maximally $0.11 \mathrm{mM}$ [equivalent to $10 \%(\mathrm{v} / \mathrm{v})$ partial $\mathrm{O}_{2}$ pressure], depending on the day of the menstrual cycle and the method used for measuring gas tensions. Vaginal $\mathrm{CO}_{2}$ levels, however, vary only slightly during the menstrual cycle $(6-8 \%, v / v)$ (Wagner \& Ottesen, 1982). Therefore, in this study we supplied $\mathrm{O}_{2}$ to cells in concentrations equivalent to a partial $\mathrm{O}_{2}$ pressure between 0.01 and $7 \%$ $(\mathrm{v} / \mathrm{v})$, in combination with $6 \%(\mathrm{v} / \mathrm{v}) \mathrm{CO}_{2}$, using batch fermenters with controlled aeration.

The growth rate of $C$. albicans on the medium selected and under an atmosphere of $7 \% \mathrm{O}_{2} / 6 \% \mathrm{CO}_{2}$ equals $0.60 \mathrm{~h}^{-1}$ (corresponding to a generation time of $\sim 70 \mathrm{~min}$; see Fig. 1), which is considerably faster than under atmospheric conditions in the same medium $\left(0.45 \mathrm{~h}^{-1}\right.$, corresponding to a generation time of $\sim 90 \mathrm{~min})$. As $S$. cerevisiae can fix $\mathrm{CO}_{2}$ via pyruvate carboxylase to form the citric acid cycle intermediate oxaloacetate, and as higher $\mathrm{CO}_{2}$ concentrations up to $\sim 6 \%$ result in increased $\mathrm{CO}_{2}$ fixation (Cazzulo et al., 1968; Liener \& Buchanan, 1951), the increased

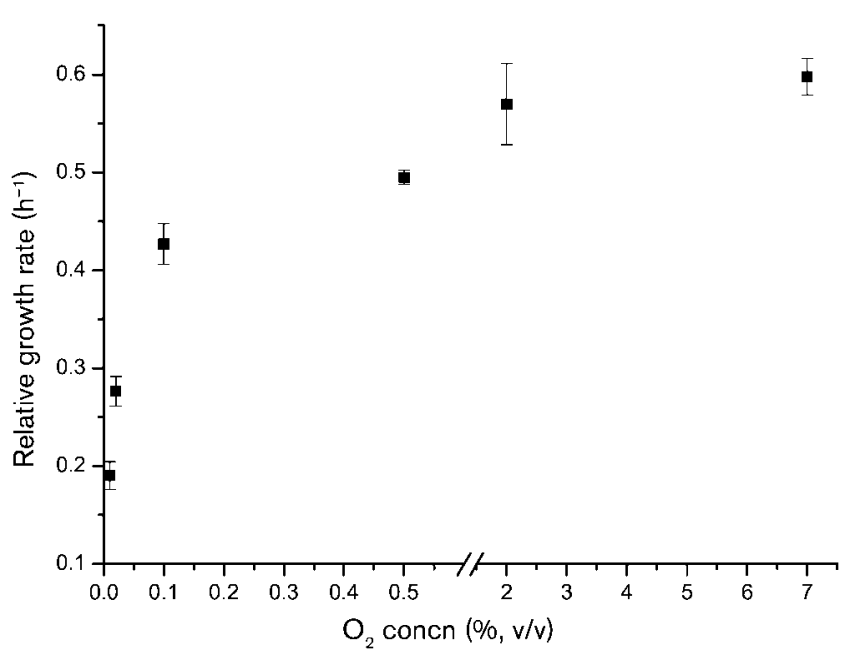

Fig. 1. The effect of lowering the $\mathrm{O}_{2}$ concentration on the relative growth rate of $\mathrm{C}$. albicans cells growing in VSM at $37{ }^{\circ} \mathrm{C}$ and at $6 \% \mathrm{CO}_{2}$. The data shown represent the means of three cultures. The error bars represent SD. 
growth rate might be caused by the elevated $\mathrm{CO}_{2}$ concentration. Fig. 1 further shows that at $7 \%(\mathrm{v} / \mathrm{v}), \mathrm{O}_{2}$ is present at a saturating concentration with respect to the growth rate. The maximal growth rate of $C$. albicans in batch culture decreases significantly, however, when the $\mathrm{O}_{2}$ level is lowered to less than $0.5 \%(\mathrm{v} / \mathrm{v}) \mathrm{O}_{2}$ and is halved at $\sim 0.02 \% \quad(\mathrm{v} / \mathrm{v})$, which corresponds to a dissolved $\mathrm{O}_{2}$ concentration of approximately $0.23 \mu \mathrm{M}$. Further experiments were carried out using an $\mathrm{O}_{2}$ level of $0.02 \%(\mathrm{v} / \mathrm{v})$.

Cells cultured in VSM at low $\mathrm{O}_{2}$ levels in combination with elevated $\mathrm{CO}_{2}$ levels grew exclusively in the yeast and pseudohyphal form, under all $\mathrm{O}_{2}$ concentrations tested; a similar morphology was observed when the cells were grown in VSM and aerated with an atmospheric gas mixture (data not shown). The lower growth rates at low $\mathrm{O}_{2}$ concentrations were accompanied by a decrease in the budding index, which dropped from $91 \%$ at $7 \% \mathrm{O}_{2}$ to $33 \%$ at $0.01 \% \mathrm{O}_{2}$, indicating that the $\mathrm{G} 1$ phase of the cell cycle is extended when cells are deprived of $\mathrm{O}_{2}$. Interestingly, lower $\mathrm{O}_{2}$ levels resulted in increased resistance of intact cells to Quantazyme, a recombinant $\beta-1,3-$ glucanase, indicating that the structure or composition of the cell wall had changed (Fig. 2). This was not reflected in significant changes in the total polypeptide content of the walls, which was $2.4 \%$ at both $7 \% \mathrm{O}_{2}(\mathrm{v} / \mathrm{v})$ and $0.02 \% \mathrm{O}_{2}$ $(\mathrm{v} / \mathrm{v})$. The respective chitin contents of these wall preparations were 3.5 and $2.9 \%$. The small differences in these cell-wall components may imply that the increased Quantazyme resistance of C. albicans is due to an altered protein composition of its wall (see next section).

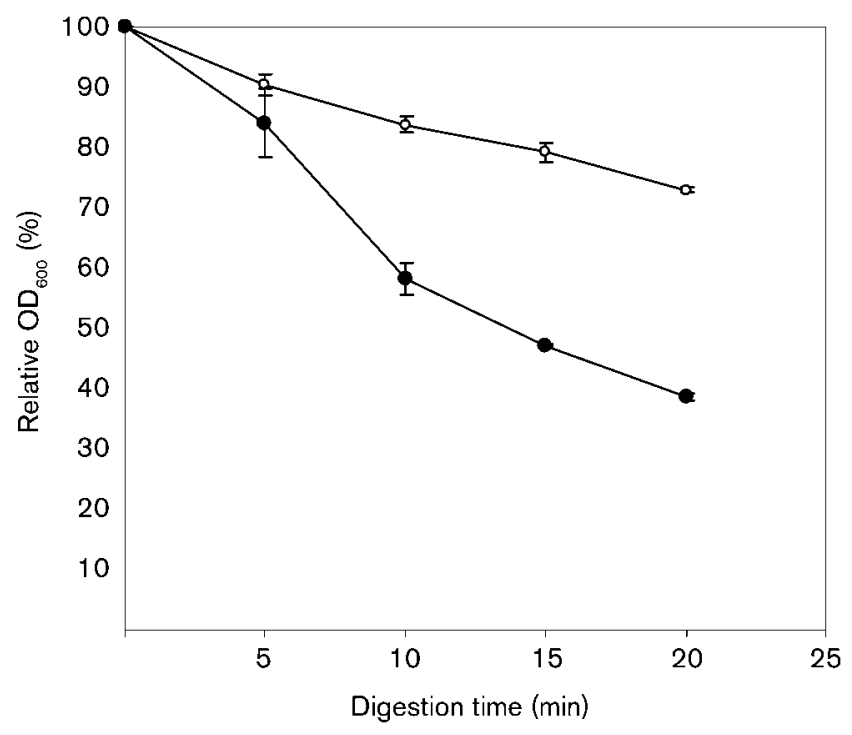

Fig. 2. Increased resistance of cells, grown under a low partial pressure of $\mathrm{O}_{2}$, to the endo- $\beta$-1,3-glucanase Quantazyme. The cells were grown at $7 \% \mathrm{O}_{2} / 6 \% \mathrm{CO}_{2}(\mathbf{O})$ or at $0.02 \% \mathrm{O}_{2} / 6 \%$ $\mathrm{CO}_{2}(\bigcirc)$. The values shown are the means of two replicates.

\section{Effects of $\mathrm{O}_{2}$ deprivation on the cell-wall proteome}

For a qualitative comparison of the covalently linked proteins in the cell wall of wild-type cells grown at $\mathrm{O}_{2}$ concentrations $\leqslant 7 \%(\mathrm{v} / \mathrm{v})$ and at $6 \% \mathrm{CO}_{2}(\mathrm{v} / \mathrm{v})$ in $\mathrm{VSM}$, we applied LC followed by tandem MS (LC/MS/MS) of CWP-derived peptides. In combination with immunoblot analysis we detected 19 proteins, including 15 known or predicted GPI proteins, and four non-GPI proteins (Table 2, Fig. 3). For comparison, cell walls obtained from a fermenter-grown reference culture grown in rich medium were also analysed. Importantly, the GPI-proteins Als3, Hwp1 and Utr2, and the non-GPI proteins Sim1 and Tos1, were only found in VSM cultures. Additionally, in VSM cultures a specific peptide confirming the presence of Rbt5 was detected, which was not identified previously (De

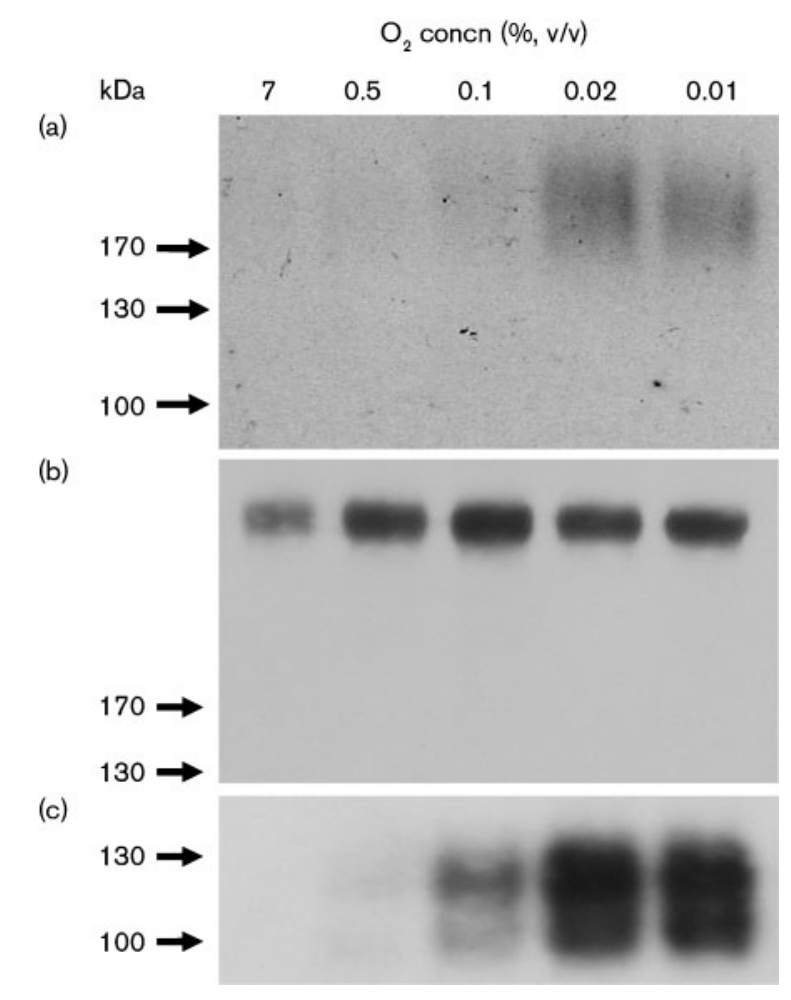

Fig. 3. $\mathrm{O}_{2}$ limitation results in increased cell-wall levels of Pir1 (a), Hwp1 (b), and Pga10 and Rbt5 (c). Cells were grown overnight in a batch fermenter under air to an $\mathrm{OD}_{600}$ of $\sim 0.1$. The cells were then cultured with controlled aeration using a gas mixture consisting of nitrogen, $6 \% \mathrm{CO}_{2}$ and $0.01-7 \% \mathrm{O}_{2}$ until an $\mathrm{OD}_{600}$ of $\sim 1$ was reached. Covalently linked CWPs were released from cell walls with mild alkali extraction (Pir1) or $\beta$-1,6-glucanase (Hwp1, Pga10, Rbt5). For each condition, proteins isolated from equal amounts of cell walls $(\sim 0.15 \mathrm{mg}$ dried walls, which corresponds to $\sim 1 \mathrm{mg}$ dried biomass) were subjected to immunoblot analysis. Sizes of marker proteins are indicated on the left. The diffuse nature of the Pir1 band is probably due to allelic variability (Candida Genome Database - www.candidagenome.org) and the high degree of glycosylation of Pir1. 
Groot et al., 2004). The transglucosylase $\mathrm{Phr} 2$ was identified in the walls at all tested $\mathrm{O}_{2}$ concentrations, consistent with its function at acidic pHs (De Bernardis et al., 1998; Fonzi, 1999; Mühlschlegel \& Fonzi, 1997). Phr2 peptides were also identified in the reference culture, probably due to the fact that during culture the $\mathrm{pH}$ of the reference culture dropped from 5.5 to 4.9 . This is consistent with the known pH-dependency of PHR2 expression (Mühlschlegel \& Fonzi, 1997). Als3, an adhesion protein that mimics mammalian cadherins (Phan et al., 2007), was also identified in all VSM samples (20 identifications of Als3 peptides; data not shown), whereas no Als3 peptides were found in the reference culture. This is consistent with the frequent occurrence of ALS3 transcripts in vaginal samples during $C$. albicans infection (Cheng et al., 2005). Als3 has been described as a hyphaspecific protein (Argimon et al., 2007; Hoyer et al., 1998); however, as our samples did not contain hyphae, our observations demonstrate that the synthesis of Als3 may also occur in non-hyphal cells under selective environmental conditions. Table 2 also shows that the peptides released by trypsin from GPI-modified CWPs and identified by tandem MS were predominantly found in the $\mathrm{N}$-terminal region of these proteins, consistent with the observation that this region generally is less serine- and threonine-rich and therefore less glycosylated (Chen et al., 1995). No such tendency was observed for the non-GPI proteins.

Because our mass spectrometric approach identified the same set of covalently linked CWPs at all $\mathrm{O}_{2}$ levels tested (data not shown), we then used an immunological approach to detect quantitative changes in the cell-wall proteome. Using a cross-reactive antiserum raised against S. cerevisiae Pir2 (Russo et al., 1992), we found increased levels of Pir1 protein in cell-wall extracts obtained with mild alkali, when the $\mathrm{O}_{2}$ level decreased below $0.02 \%(\mathrm{v} / \mathrm{v})$ (Fig. 3a). As Pir1 protein is a potential $\beta$-1,3-glucan crosslinking protein and essential for cell-wall integrity (Klis et al., 2007; Martinez et al., 2004), this might explain the increased Quantazyme resistance of intact cells grown at low $\mathrm{O}_{2}$ levels.

As the expression of $H W P 1$ is increased in non-hyphal cells grown under hypoxic conditions (Setiadi et al., 2006), we also quantitatively analysed Hwp1 levels. Fig. 3(b) shows that Hwp1 was indeed present in the walls isolated from cells grown under vagina-simulative conditions at all $\mathrm{O}_{2}$ concentrations tested and that its level increased at hypoxic $\mathrm{O}_{2}$ levels. Nevertheless, the highest levels observed under these conditions were still significantly lower than the levels found in hyphal walls; Hwp1 was not found in walls of cells grown in rich medium even after overexposure of the immunoblots (data not shown).

The transcript levels of RBT5, which encodes a predicted GPI protein involved in iron acquisition (De Groot et al., 2003; Weissman \& Kornitzer, 2004), also showed a considerable increase under hypoxic conditions (Setiadi et al., 2006). Fig. 3(c) shows that an antiserum raised against Pga10, a homologue of Rbt5 and also involved in iron acquisition (Weissman \& Kornitzer, 2004), identified two bands with molecular masses of about 100 and $130 \mathrm{kDa}$ at an $\mathrm{O}_{2}$ concentration of $\leqslant 0.5 \%(\mathrm{v} / \mathrm{v})$. To investigate if these bands represented Rbt 5 and Pgal0 or other members of the family (Weissman \& Kornitzer, 2004), we analysed the homozygous single-deletion mutants and the double deletant. Fig. 4 shows that the two bands incorporated in the cell wall of the control strain (CAF2-1) were not present in the double-deletion strain and that only a single band is detected in each of the single mutant strains grown under low- $\mathrm{O}_{2}$ conditions. This is consistent with the notion that the $100 \mathrm{kDa}$ band corresponds to Rbt5 and the $130 \mathrm{kDa}$ band to Pga10. Interestingly, PGA10 and RBT5 belong to the same transcriptional module as HWP1 (level 16, module 16; see also the Candida Genome Database - www. candidagenome.org; Ihmels et al., 2005), showing that these three genes are co-regulated under several other test conditions as well.

Because the high-affinity iron-uptake system of C. albicans requires molecular $\mathrm{O}_{2}$ (Kosman, 2003), hypoxic conditions are expected to lead to iron deprivation, raising the question whether iron deprivation alone might induce similar changes in the cell-wall proteome as $\mathrm{O}_{2}$ limitation. Fig. 5 shows that the changes in the cell-wall proteome of cells treated with the ferrous iron chelator ferrozine $(1 \mathrm{mM}$, resulting in a limited decrease in relative growth rate from 0.60 to $0.55 \mathrm{~h}^{-1}$ ) partially overlapped with the changes observed in the cell-wall proteome of cells grown under hypoxic conditions. The levels of Rbt5 and Hwp1 in cell walls increased in both ferrozine-treated cells and in

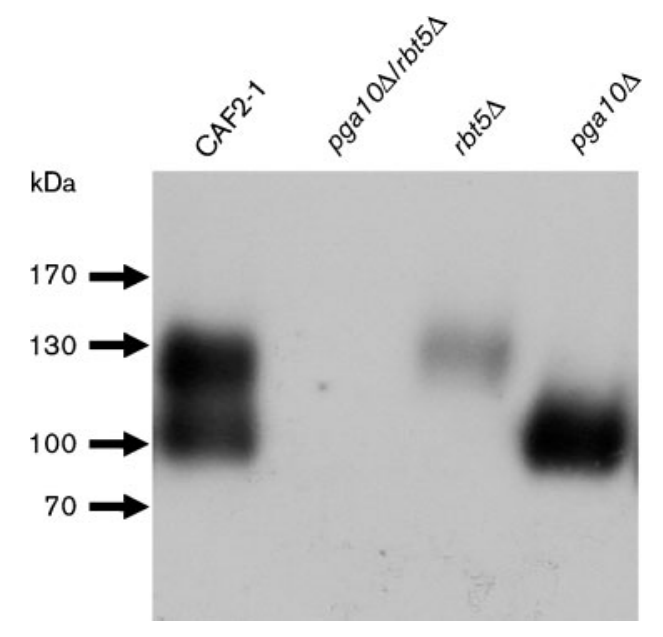

Fig. 4. Immunoblot analysis of the Rbt5 family of proteins in $r b t 5 \Delta$ and pga10 10 mutant strains using a Pga10 antiserum. The cells were grown in VSM at $0.02 \% \mathrm{O}_{2} / 6 \% \mathrm{CO}_{2}(\mathrm{v} / \mathrm{v})$. CWPs were released using $\beta$-1,6-glucanase. 
cells grown under hypoxic conditions, but in ferrozinetreated cells the levels of Pir1 and Pga10 were not increased.

\section{DISCUSSION}

CWPs of C. albicans play a major role in the infection of mucosal surfaces in the human body, including the vaginal mucosal surface. Vaginal environmental conditions are characterized, among others, by a growth temperature of $37^{\circ} \mathrm{C}$, an acidic $\mathrm{pH}$ and by an increased concentration of $\mathrm{CO}_{2}$ and low concentrations of $\mathrm{O}_{2}$ compared to atmospheric values. Here we have studied the effect of vaginal growth conditions on the cell-wall proteome and, in particular, the effect of low $\mathrm{O}_{2}$ concentrations. In the VSM that we developed for our studies, no hyphal growth was observed under any of the conditions tested. It is important to realize that the medium used in this study and the way in which the cells were grown do not fully mimic vaginal conditions. For example, VSM contains YNB, but no sterols or fatty acids, both of which may be expected to be present under in vivo conditions. In addition, Candida cells might grow in the vagina in the form of biomats or biofilms, whereas cells in our experiments were cultured in a rapidly stirred and fully aerated fermenter.

Using a combination of tandem MS and immunoblot analysis, we identified 19 CWPs, five of which (Als3, Hwp1, Sim1, Tos1 and Utr2) were not found in a reference culture grown in rich medium. This is in agreement with earlier results (De Groot et al., 2004). This supports the notion that the composition of the cell-wall proteome of $C$. albicans is tightly controlled. The presence of $\mathrm{Phr} 2$ in the cell walls is in agreement with earlier observations showing that PHR2 is specifically expressed at $\mathrm{pHs}$ below $\mathrm{pH} 5.5$ and that the resulting protein is directly involved in cell wall assembly and is essential for colonization of the vagina (De Bernardis et al., 1998; Fonzi, 1999; Mühlschlegel \& Fonzi, 1997). Immunoblot analysis identified the presence of an additional GPI protein (Hwp1), which was missed by our MS analysis due to the lack of suitable tryptic peptides (i.e. not heavily glycosylated and with a mass that does not exceed the detection limit of the mass spectrometer). Both
Als3 and Hwp1 have been described as hypha-specific adhesion proteins (Argimon et al., 2007; Hoyer et al., 1998; Staab et al., 1999). However, as our cultures did only contain yeast and pseudohyphal cells, our results show that both proteins can also be expressed in non-hyphal cells, depending on the specific growth conditions. This is consistent with the observation that HWP1 is moderately expressed in pseudohyphal cells (Snide \& Sundstrom, 2006). Interestingly, ALS3 transcripts have been frequently detected in clinical vaginal fluid specimens, suggesting that the adhesion protein Als3 is important for colonization of this environment (Cheng et al., 2005).

$\mathrm{O}_{2}$ limitation affects multiple processes in eukaryotic cells, such as iron uptake, mitochondrial respiration, sterol synthesis and the synthesis of unsaturated fatty acids, all of which at some stage require molecular $\mathrm{O}_{2}$ (Berg et al., 2007; Kosman, 2003; Schweizer, 2004). There are several indications that the hypoxic conditions used in our study result in a molecular response that resembles the response observed when cells grow under iron-restricted conditions. First, when the $\mathrm{O}_{2}$ concentrations were lowered, the levels of the iron-acquisition proteins Pga10 and Rbt5 in the cell wall increased. Second, intact cells became more resistant to the endo- $\beta$-1,3-glucanase Quantazyme (Fig. 2) and to the cell-wall-degrading enzyme preparation Zymolyase (data not shown). This is in agreement with the observation that iron limitation in C. albicans results in increased resistance of intact cells to Zymolyase (Sweet \& Douglas, 1991). Third, genomic transcript analyses have revealed that iron-acquisition and iron-uptake genes, including $R B T 5$, are not only upregulated in cells grown at low-iron conditions (Lan et al., 2004; Weissman \& Kornitzer, 2004), but also under hypoxic conditions (Setiadi et al., 2006). Finally, addition of the iron-chelating compound ferrozine to the medium, at saturating $\mathrm{O}_{2}$ levels, resulted in an increased level of Rbt5 in the wall (Fig. 5). This is in agreement with the observation that the antifungal agent ciclopirox, which is believed to possess iron-chelating properties as well, strongly increases the transcript level of RBT5 (Lee et al., 2005; Sigle et al., 2005). Interestingly, the presence of ferrozine in the medium also caused an increase in the cell wall of the adhesion protein

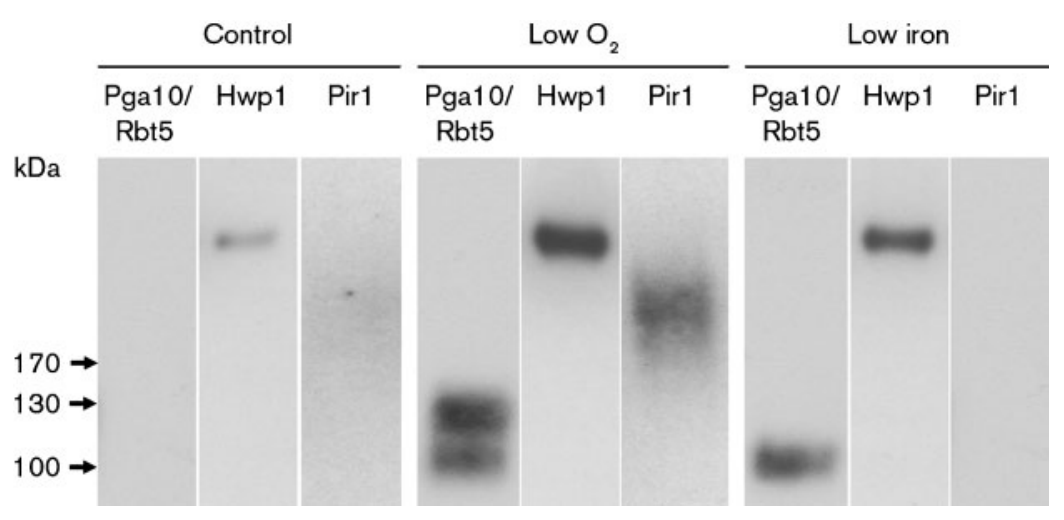

Fig. 5. Western blot analysis of CWPs from cells grown at $7 \% \quad \mathrm{O}_{2} / 6 \% \mathrm{CO}_{2}$ (control), $0.02 \% \mathrm{O}_{2} / 6 \% \mathrm{CO}_{2}$ (low- $\mathrm{O}_{2}$ conditions) or $7 \% \mathrm{O}_{2} / 6 \% \mathrm{CO}_{2}$ in the presence of $1 \mathrm{mM}$ ferrozine (low-iron conditions). Covalently linked CWPs were released from cell walls with $\beta$-1,6-glucanase (Pga10, Rbt5 and Hwp1) or by mild alkali extraction (Pir1) as described in Methods. 
Hwp1, suggesting an additional control mechanism for HWP1 expression. We propose that hypoxic conditions result in reduced iron uptake and competition for iron by iron-containing enzymes and that this might lead in various ways to increased expression of specific CWPencoding genes. Another explanation for the response to hypoxic conditions may reside in the fact that numerous $\mathrm{O}_{2}$-dependent reactions in the cell are carried out by ironcontaining enzymes [e.g. haems in respiration and Fedependent sterol synthesis (Kaplan et al., 2006)]. Maintaining a sufficiently high rate of $\mathrm{O}_{2}$-dependent enzymic reactions could therefore be achieved by an increased synthesis of iron-containing enzymes. To be able to do so, an increase in iron-scavenging proteins like PGA10 and RBT5 would indeed be expected. Our results do not exclude that processes such as sterol synthesis and the synthesis of unsaturated fatty acids, which are affected by the low $\mathrm{O}_{2}$ concentrations used in our study, might also cause major changes in (plasma) membrane properties indirectly affecting the cell wall as well. Indeed, several CWPs (Ecm33, Phr2, Pga10, Pir1 and Rbt5; see Table 2) are induced when the cells are treated with azoles, which are known to affect ergosterol synthesis. We conclude that the cell-wall proteome of $C$. albicans sensitively reflects the environmental conditions and helps the cell to adjust to stress conditions encountered during the infection process. Our results also show that the composition of the cell-wall proteome is tightly controlled, and that multiple signalling pathways are involved in the regulation of its composition.

\section{ACKNOWLEDGEMENTS}

We thank Daniel Kornitzer, Marja Makarow and Paula Sundstrom for antisera and strains. This project was funded by EU project GALAR FUNGAIL II (MRTN-CT-2003-504148).

\section{REFERENCES}

Albrecht, A., Felk, A., Pichova, I., Naglik, J. R., Schaller, M., de Groot, P., Maccallum, D., Odds, F. C., Schäfer, W. \& other authors (2006). Glycosylphosphatidylinositol-anchored proteases of Candida albicans target proteins necessary for both cellular processes and host-pathogen interactions. J Biol Chem 281, 688-694.

Argimon, S., Wishart, J. A., Leng, R., Macaskill, S., Mavor, A., Alexandris, T., Nicholls, S., Knight, A. W., Enjalbert, B. \& other authors (2007). Developmental regulation of an adhesin gene during cellular morphogenesis in the fungal pathogen Candida albicans. Eukaryot Cell 6, 682-692.

Bensen, E. S., Martin, S. J., Li, M., Berman, J. \& Davis, D. A. (2004). Transcriptional profiling in Candida albicans reveals new adaptive responses to extracellular $\mathrm{pH}$ and functions for Rim101p. Mol Microbiol 54, 1335-1351.

Berg, J. M., Tymoczko, J. L. \& Stryer, L. (2007). Biochemistry, 6th edn. New York: W. H. Freeman.

Blankenship, J. R. \& Mitchell, A. P. (2006). How to build a biofilm: a fungal perspective. Curr Opin Microbiol 9, 588-594.

Bom, I. J., Dielbandhoesing, S. K., Harvey, K. N., Oomes, S. J., Klis, F. M. \& Brul, S. (1998). A new tool for studying the molecular architecture of the fungal cell wall: one-step purification of recombinant trichoderma $\beta$-(1-6)-glucanase expressed in Pichia pastoris. Biochim Biophys Acta 1425, 419-424.

Braun, B. R., Head, W. S., Wang, M. X. \& Johnson, A. D. (2000). Identification and characterization of TUP1-regulated genes in Candida albicans. Genetics 156, 31-44.

Calderone, R. A. (2002). Taxonomy and biology of Candida. In Candida and Candidiasis, pp. 15-27. Edited by R. A. Calderone. Washington, DC: American Society for Microbiology.

Cazzulo, J. J., Claisse, L. M. \& Stoppani, A. O. (1968). Carboxylase levels and carbon dioxide fixation in baker's yeast. J Bacteriol 96, 623-628.

Chen, M. H., Shen, Z. M., Bobin, S., Kahn, P. C. \& Lipke, P. N. (1995). Structure of Saccharomyces cerevisiae $\alpha$-agglutinin. Evidence for a yeast cell wall protein with multiple immunoglobulin-like domains with atypical disulfides. J Biol Chem 270, 26168-26177.

Cheng, G., Wozniak, K., Wallig, M. A., Fidel, P. L., Jr, Trupin, S. R. \& Hoyer, L. L. (2005). Comparison between Candida albicans agglutinin-like sequence gene expression patterns in human clinical specimens and models of vaginal candidiasis. Infect Immun 73, 1656-1663.

Copping, V. M., Barelle, C. J., Hube, B., Gow, N. A., Brown, A. J. \& Odds, F. C. (2005). Exposure of Candida albicans to antifungal agents affects expression of $S A P 2$ and $S A P 9$ secreted proteinase genes. $J$ Antimicrob Chemother 55, 645-654.

De Backer, M. D., Ilyina, T., Ma, X. J., Vandoninck, S., Luyten, W. H. \& Vanden Bossche, H. (2001). Genomic profiling of the response of Candida albicans to itraconazole treatment using a DNA microarray. Antimicrob Agents Chemother 45, 1660-1670.

De Bernardis, F., Muhlschlegel, F. A., Cassone, A. \& Fonzi, W. A. (1998). The $\mathrm{pH}$ of the host niche controls gene expression in and virulence of Candida albicans. Infect Immun 66, 3317-3325.

De Groot, P. W. J., Hellingwerf, K. J. \& Klis, F. M. (2003). Genomewide identification of fungal GPI proteins. Yeast 20, 781-796.

De Groot, P. W. J., De Boer, A. D., Cunningham, J., Dekker, H. L., De Jong, L., Hellingwerf, K. J., De Koster, C. \& Klis, F. M. (2004). Proteomic analysis of Candida albicans cell walls reveals covalently bound carbohydrate-active enzymes and adhesins. Eukaryot Cell 3, 955-965.

De Groot, P. W. J., Brandt, B. W. \& Klis, F. M. (2007). Cell wall biology of Candida. In Candida Comparative and Functional Genomics, pp. 293-325. Norfolk: Caister Academic Press.

Fidel, P. L. J. \& Sobel, J. D. (2002). Host defense against vaginal candidiasis. In Candida and Candidiasis, pp. 193-209. Washington, DC: American Society for Microbiology.

Fonzi, W. A. (1999). PHR1 and PHR2 of Candida albicans encode putative glycosidases required for proper cross-linking of $\beta$-1,3-and $\beta$-1,6-glucans. J Bacteriol 181, 7070-7079.

Fonzi, W. A. \& Irwin, M. Y. (1993). Isogenic strain construction and gene mapping in Candida albicans. Genetics 134, 717-728.

Fradin, C., De Groot, P., MacCallum, D., Schaller, M., Klis, F., Odds, F. C. \& Hube, B. (2005). Granulocytes govern the transcriptional response, morphology and proliferation of Candida albicans in human blood. Mol Microbiol 56, 397-415.

Garcera, A., Martinez, A. I., Castillo, L., Elorza, M. V., Sentandreu, R. \& Valentin, E. (2003). Identification and study of a Candida albicans protein homologous to Saccharomyces cerevisiae Ssrlp, an internal cell-wall protein. Microbiology 149, 2137-2145.

Garcera, A., Castillo, L., Martinez, A. I., Elorza, M. V., Valentin, E. \& Sentandreu, R. (2005). Anchorage of Candida albicans Ssr1 to the cell wall, and transcript profiling of the null mutant. Res Microbiol 156, 911-920. 
Garcia-Sanchez, S., Aubert, S., Iraqui, I., Janbon, G., Ghigo, J. M. \& d'Enfert, C. (2004). Candida albicans biofilms: a developmental state associated with specific and stable gene expression patterns. Eukaryot Cell 3, 536-545.

Granger, B. L., Flenniken, M. L., Davis, D. A., Mitchell, A. P. \& Cutler, J. E. (2005). Yeast wall protein 1 of Candida albicans. Microbiology 151, 1631-1644.

Hoyer, L. L., Payne, T. L., Bell, M., Myers, A. M. \& Scherer, S. (1998). Candida albicans ALS3 and insights into the nature of the ALS gene family. Curr Genet 33, 451-459.

Ihmels, J., Bergmann, S., Berman, J. \& Barkai, N. (2005). Comparative gene expression analysis by differential clustering approach: application to the Candida albicans transcription program. PLoS Genet 1, e39.

Kaplan, J., McVey Ward, D., Crisp, R. J. \& Philpott, C. C. (2006). Irondependent metabolic remodeling in S. cerevisiae. Biochim Biophys Acta 1763, 646-651.

Kapteyn, J. C., Ter Riet, B., Vink, E., Blad, S., De Nobel, H., Van den Ende, H. \& Klis, F. M. (2001). Low external pH induces HOG1dependent changes in the organization of the Saccharomyces cerevisiae cell wall. Mol Microbiol 39, 469-479.

Klis, F. M., Ram, A. F. J. \& De Groot, P. W. J. (2007). A molecular and genomic view of the fungal cell wall. In Biology of the Fungal Cell, pp. 97-120. Edited by R. J. Howard \& N. A. R. Gow. Berlin, Heidelberg: Springer-Verlag.

Klotz, S. A., Gaur, N. K., De Armond, R., Sheppard, D., Khardori, N., Edwards, J. E., Jr, Lipke, P. N. \& El-Azizi, M. (2007). Candida albicans Als proteins mediate aggregation with bacteria and yeasts. Med Mycol 45, 363-370.

Kosman, D. J. (2003). Molecular mechanisms of iron uptake in fungi. Mol Microbiol 47, 1185-1197.

Lan, C. Y., Rodarte, G., Murillo, L. A., Jones, T., Davis, R. W., Dungan, J., Newport, G. \& Agabian, N. (2004). Regulatory networks affected by iron availability in Candida albicans. Mol Microbiol 53, 1451-1469.

Lee, R. E., Liu, T. T., Barker, K. S., Lee, R. E. \& Rogers, P. D. (2005). Genome-wide expression profiling of the response to ciclopirox olamine in Candida albicans. J Antimicrob Chemother 55, 655-662.

Li, F., Svarovsky, M. J., Karlsson, A. J., Wagner, J. P., Marchillo, K., Oshel, P., Andes, D. \& Palecek, S. P. (2007). Eaplp, an adhesin that mediates Candida albicans biofilm formation in vitro and in vivo. Eukaryot Cell 6, 931-939.

Liener, I. E. \& Buchanan, D. L. (1951). The fixation of carbon dioxide by growing and nongrowing yeast. J Bacteriol 61, 527-534.

Liu, T. T., Lee, R. E. B., Barker, K. S., Lee, R. E., Wei, L., Homayouni, R. \& Rogers, P. D. (2005). Genome-wide expression profiling of the response to azole, polyene, echinocandin, and pyrimidine antifungal agents in Candida albicans. Antimicrob Agents Chemother 49, 2226-2236.

Mao, Y., Zhang, Z. \& Wong, B. (2003). Use of green fluorescent protein fusions to analyse the $\mathrm{N}$ - and C-terminal signal peptides of GPI-anchored cell wall proteins in Candida albicans. Mol Microbiol 50, 1617-1628.

Martchenko, M., Alarco, A. M., Harcus, D. \& Whiteway, M. (2004). Superoxide dismutases in Candida albicans: transcriptional regulation and functional characterization of the hyphal-induced SOD5 gene. Mol Biol Cell 15, 456-467.

Martinez, A. I., Castillo, L., Garcera, A., Elorza, M. V., Valentin, E. \& Sentandreu, R. (2004). Role of Pirl in the construction of the Candida albicans cell wall. Microbiology 150, 3151-3161.

Martinez-Lopez, R., Park, H., Myers, C. L., Gil, C. \& Filler, S. G. (2006). Candida albicans Ecm $33 p$ is important for normal cell wall architecture and interactions with host cells. Eukaryot Cell 5, 140-147.
McCreath, K. J., Specht, C. A. \& Robbins, P. W. (1995). Molecular cloning and characterization of chitinase genes from Candida albicans. Proc Natl Acad Sci U S A 92, 2544-2548.

Moosa, M. Y., Sobel, J. D., Elhalis, H., Du, W. \& Akins, R. A. (2004). Fungicidal activity of fluconazole against Candida albicans in a synthetic vagina-simulative medium. Antimicrob Agents Chemother 48, 161-167.

Mrša, V., Seidl, T., Gentzsch, M. \& Tanner, W. (1997). Specific labelling of cell wall proteins by biotinylation. Identification of four covalently linked $\mathrm{O}$-mannosylated proteins of Saccharomyces cerevisiae. Yeast 13, 1145-1154.

Mühlschlegel, F. A. \& Fonzi, W. A. (1997). PHR2 of Candida albicans encodes a functional homolog of the $\mathrm{pH}$-regulated gene $P H R 1$ with an inverted pattern of pH-dependent expression. Mol Cell Biol 17, 5960-5967.

Naglik, J. R., Fostira, F., Ruprai, J., Staab, J. F., Challacombe, S. J. \& Sundstrom, P. (2006). Candida albicans HWP1 gene expression and host antibody responses in colonization and disease. J Med Microbiol 55, 1323-1327.

Nobile, C. J., Nett, J. E., Andes, D. R. \& Mitchell, A. P. (2006). Function of Candida albicans adhesin Hwp1 in biofilm formation. Eukaryot Cell 5, 1604-1610.

Owen, D. H. \& Katz, D. F. (1999). A vaginal fluid simulant. Contraception 59, 91-95.

Pardini, G., De Groot, P. W. J., Coste, A. T., Karababa, M., Klis, F. M., de Koster, C. G. \& Sanglard, D. (2006). The CRH family coding for cell wall glycosylphosphatidylinositol proteins with a predicted transglycosidase domain affects cell wall organization and virulence of Candida albicans. J Biol Chem 281, 40399-40411.

Phan, Q. T., Myers, C. L., Fu, Y., Sheppard, D. C., Yeaman, M. R., Welch, W. H., Ibrahim, A. S., Edwards, J. E. \& Filler, S. G. (2007). Als3 is a Candida albicans invasin that binds to cadherins and induces endocytosis by host cells. PLoS Biol 5, e64.

Ramage, G., Martinez, J. P. \& Lopez-Ribot, J. L. (2006). Candida biofilms on implanted biomaterials: a clinically significant problem. FEMS Yeast Res 6, 979-986.

Richard, M. L. \& Plaine, A. (2007). Comprehensive analysis of glycosylphosphatidylinositol-anchored proteins in Candida albicans. Eukaryot Cell 6, 119-133.

Ruiz-Herrera, J., Elorza, M. V., Valentin, E. \& Sentandreu, R. (2006). Molecular organization of the cell wall of Candida albicans and its relation to pathogenicity. FEMS Yeast Res 6, 14-29.

Russo, P., Kalkkinen, N., Sareneva, H., Paakkola, J. \& Makarow, M. (1992). A heat shock gene from Saccharomyces cerevisiae encoding a secretory glycoprotein. Proc Natl Acad Sci U S A 89, 3671-3675.

Sandini, S., La Valle, R., De Bernardis, F., Macri, C. \& Cassone, A. (2007). The $65 \mathrm{kDa}$ mannoprotein gene of Candida albicans encodes a putative $\beta$-glucanase adhesin required for hyphal morphogenesis and experimental pathogenicity. Cell Microbiol 9, 1223-1238.

Schweizer, M. (2004). Lipids and membranes. In The Metabolism and Molecular Physiology of Saccharomyces cerevisiae, pp. 140-223. Edited by J. R. Dickinson \& M. Schweizer. Boca Raton: CRC Press.

Setiadi, E. R., Doedt, T., Cottier, F., Noffz, C. \& Ernst, J. F. (2006). Transcriptional response of Candida albicans to hypoxia: linkage of oxygen sensing and Efglp-regulatory networks. J Mol Biol 361, 399-411.

Sigle, H. C., Thewes, S., Niewerth, M., Korting, H. C., SchaferKorting, M. \& Hube, B. (2005). Oxygen accessibility and iron levels are critical factors for the antifungal action of ciclopirox against Candida albicans. J Antimicrob Chemother 55, 663-673.

Snide, J. L. \& Sundstrom, P. (2006). A characterization of HWP1 promoter activation in pseudohyphal cells in Candida albicans. In 8 th ASM Conference on Candida and Candidiasis, pp. 103. Washington, DC: American Society for Microbiology. 
Sobel, J. D. (2007). Vulvovaginal candidosis. Lancet 369, 1961-1971. Sohn, K., Urban, C., Brunner, H. \& Rupp, S. (2003). EFG1 is a major regulator of cell wall dynamics in Candida albicans as revealed by DNA microarrays. Mol Microbiol 47, 89-102.

Sohn, K., Senyurek, I., Fertey, J., Konigsdorfer, A., Joffroy, C., Hauser, N., Zelt, G., Brunner, H. \& Rupp, S. (2006). An in vitro assay to study the transcriptional response during adherence of Candida albicans to different human epithelia. FEMS Yeast Res 6, 1085-1093.

Staab, J. F., Ferrer, C. A. \& Sundstrom, P. (1996). Developmental expression of a tandemly repeated, proline-and glutamine-rich amino acid motif on hyphal surfaces on Candida albicans. J Biol Chem 271, 6298-6305.

Staab, J. F., Bradway, S. D., Fidel, P. L. \& Sundstrom, P. (1999). Adhesive and mammalian transglutaminase substrate properties of Candida albicans Hwp1. Science 283, 1535-1538.

Sundstrom, P. (1999). Adhesins in Candida albicans. Curr Opin Microbiol 2, 353-357.

Sweet, S. P. \& Douglas, L. J. (1991). Effect of iron deprivation on surface composition and virulence determinants of Candida albicans. J Gen Microbiol 137, 859-865.
Wagner, G. \& Ottesen, B. (1982). Vaginal physiology during menstruation. Ann Intern Med 96, 921-923.

Weissman, Z. \& Kornitzer, D. (2004). A family of Candida cell surface haem-binding proteins involved in haemin and haemoglobin-iron utilization. Mol Microbiol 53, 1209-1220.

Yin, Q. Y., de Groot, P. W. J., Dekker, H. L., de Jong, L., Klis, F. M. \& de Koster, C. G. (2005). Comprehensive proteomic analysis of Saccharomyces cerevisiae cell walls: identification of proteins covalently attached via glycosylphosphatidylinositol remnants or mild alkali-sensitive linkages. J Biol Chem 280, 20894-20901.

Zhao, X., Daniels, K. J., Oh, S. H., Green, C. B., Yeater, K. M., Soll, D. R. \& Hoyer, L. L. (2006). Candida albicans Als3p is required for wild-type biofilm formation on silicone elastomer surfaces. Microbiology 152, 2287-2299.

Zupancic, M. L. \& Cormack, B. P. (2007). Candida cell wall proteins at the host-pathogen interface. In Candida Comparative and Functional Genomics, pp. 327-348. Edited by C. D’Enfert \& B. Hube. Norfolk: Caister Academic Press.

Edited by: J. G. Berman 